\title{
Management of preterm severe preeclampsia: interventional versus expectant management
}

\author{
Anitha Durairaj* \\ Department of Obstetrics and Gynecology, Velammal Medical College Hospital and Research Institute, Madurai, \\ Tamil Nadu, India
}

Received: 08 September 2018

Accepted: 17 September 2018

*Correspondence:

Dr. Anitha Durairaj,

E-mail: dranithasrinidhi@gmail.com

Copyright: $\odot$ the author(s), publisher and licensee Medip Academy. This is an open-access article distributed under the terms of the Creative Commons Attribution Non-Commercial License, which permits unrestricted non-commercial use, distribution, and reproduction in any medium, provided the original work is properly cited.

\begin{abstract}
Background: Management of preterm severe preeclampsia is challenging. This study aims to determine the maternal and perinatal outcomes in interventional and expectant management.

Methods: This was a prospective study conducted at Institute of obstetrics and gynecology, Chennai over a period of three years. Patients with preterm severe preeclampsia of gestational age 28 weeks to 31 weeks and 6 days who had interventional and expectant management were recruited. Clinical details relevant to maternal, fetal and neonatal outcome were collected and the data were analyzed using IBM.SPSS statistics software 23.0 Version.

Results: Termination of pregnancy in the expectant management was done mostly for maternal indications (66\%). The mean prolongation of pregnancy in the expectant management was 7.67 days and it was statistically significant. Though maternal complications were slightly higher with the expectant management, but it was not statistically significant. Early neonatal death, perinatal death and mean NICU stay were lower in the expectant management with statistical significance. Mean gestational age at delivery, mean birth weight and neonatal survival rate were statistically significantly higher in the expectant management than the interventional management.

Conclusions: Optimizing maternal and perinatal outcome is the key in the management of preterm severe preeclampsia. Expectant management of preterm severe preeclampsia results in a better obstetric outcome and should be done only in well selected patients in a tertiary care centre.
\end{abstract}

Keywords: Expectant management, Interventional management, Preterm severe preeclampsia

\section{INTRODUCTION}

Preeclampsia complicating pregnancy is a common multisystem disorder, characterized by blood pressure $\geq 140 / 90 \mathrm{mmHg}$ with proteinuria $\geq 300 \mathrm{mg}$ after 20 weeks of gestation. Preeclampsia contributes significantly to maternal morbidity and mortality. Management of preterm mild preeclampsia, the conventional strategy is balancing the maternal and fetal outcome. On the contrary, management of women with preterm severe preeclampsia has been delivering without delay, regardless of fetal outcome. With the advancement of maternal and fetal surveillance and neonatal care facilities, several researchers have challenged the traditional idea that women with women with preterm severe preeclampsia need to be delivered expectantly.

Recent trend recommends expectant management in selected group of women with women with preterm severe preeclampsia with the aim of improving the fetal outcome without compromising maternal safety. ${ }^{1,2}$

The objective of the present study was to compare the benefits and risk of interventional and expectant management in women with preterm severe preeclampsia of gestational age 28 to 32 weeks, and to determine 
which is more beneficial by comparing the maternal and perinatal outcome.

\section{METHODS}

This was a prospective observational study conducted in the Institute of obstetrics and Gynaecology, Madras medical college, Chennai, Tamil Nadu over a period of 3 years from 2008 to 2011, after obtaining institutional ethical committee approval. Informed consent was taken.

Women with severe preeclampsia of gestational age 28 to 32 weeks were included in the study. Women with severe preeclampsia with multifetal gestation, preterm labour, rupture of membrane, congenital anomaly and complications like abruption, eclampsia, pulmonary edema, renal impairment, HELLP and DIC on admission were excluded from the study.

Patients with severe preeclampsia were admitted in labour ward. After initial evaluation and stabilization, magnesium sulphate was administered in selected patients and steroid was administered to all patients.

In the interventional management, this was followed by termination of pregnancy. Patients who delivered between 48 to 96 hours of admission and steroid administration were included in the interventional management group.

In the expectant management, this was followed by intensive maternal and fetal surveillance and termination of pregnancy was done only for a specific indication. Maternal monitoring is done by 4th hourly vitals, daily weight, urine albumin, input output chart, biweekly platelet count and liver function test.

Fetal monitoring was done by daily fetal movement count, cardiotocography, biweekly fetal doppler and weekly USG for fetal growth. At any time during the concerned period of prolongation of pregnancy, if contraindication appears expectant management was terminated. Patients who delivered after 96 hours of admission were included in the expectant management group.

In both groups, the mode of delivery was dictated by the cervical favorability, maternal and fetal condition with continued intensive intrapartum and postpartum care.

\section{Statistical analysis}

Statistical analysis of collected data were done using IBM. SPSS statistics software 23.0 Version.

\section{RESULTS}

There were 258 patients with severe preeclampsia of gestational age 28 to 32 weeks. 200 patients who received full dose of steroid were included in the study.
Table 1 represents the clinical characteristics of women with severe preeclampsia. $62.5 \%$ of patients were in the age group 20-29 years. $64.5 \%$ of severe preeclamptic women were primi gravida. Both the groups were similarly matched with respect to age, parity and gestational age on admission.

Table 1: Clinical characteristic of women with severe preeclampsia.

\begin{tabular}{|c|c|c|c|}
\hline $\begin{array}{l}\text { Clinical } \\
\text { characteristic }\end{array}$ & $\begin{array}{l}\text { Interventional } \\
\text { management } \\
(n=100)\end{array}$ & $\begin{array}{l}\text { Expectant } \\
\text { management } \\
(n=100)\end{array}$ & $\begin{array}{l}P \\
\text { value }\end{array}$ \\
\hline \multicolumn{3}{|l|}{ Maternal age } & \multirow{4}{*}{0.817} \\
\hline$\leq 19$ years & 16 & 13 & \\
\hline 20-29 years & 62 & 63 & \\
\hline$\geq 30$ years & 22 & 24 & \\
\hline \multicolumn{3}{|l|}{ Parity } & \multirow{3}{*}{0.301} \\
\hline Primi & 61 & 68 & \\
\hline Multi & 39 & 32 & \\
\hline \multicolumn{3}{|c|}{ Gestational age on admission } & \multirow{3}{*}{0.669} \\
\hline $\begin{array}{l}28 \text { to } 29 \text { weeks } \\
\text { and } 6 \text { days }\end{array}$ & 45 & 42 & \\
\hline $\begin{array}{l}30 \text { to } 31 \text { weeks } \\
\text { and } 6 \text { days }\end{array}$ & 55 & 58 & \\
\hline
\end{tabular}

Table 2 represents the indications for termination of pregnancy in the expectant management. Maternal condition $(66 \%)$ dictated termination of pregnancy in the expectant management more commonly than fetal condition $(34 \%)$.

The frequent maternal indications were imminent symptoms and uncontrolled blood pressure. The frequent fetal indication was fetal compromise (abnormal doppler or BPP).

Table 2: Indications for termination of pregnancy in the expectant management.

\begin{tabular}{|l|l|}
\hline $\begin{array}{l}\text { Indications for termination } \\
\text { of pregnancy }\end{array}$ & $\begin{array}{l}\text { Expectant management } \\
(\mathrm{n}=100)\end{array}$ \\
\hline Maternal indications & \\
\hline Imminent symptoms & 31 \\
\hline Uncontrolled blood pressure & 23 \\
\hline Abruption & 08 \\
\hline HELLP & 01 \\
\hline Eclampsia & 01 \\
\hline Pulmonary edema & 01 \\
\hline Renal impairment & 01 \\
\hline Fetal indications & \\
\hline Worsening of fetal doppler & 15 \\
\hline Severe oligohydramnios & 11 \\
\hline $\begin{array}{l}\text { Fetal distress (abnormal } \\
\text { NST/BPP) }\end{array}$ & 08 \\
\hline
\end{tabular}

Table 3 represents mode of delivery in women with preterm severe preeclampsia. The cesarean delivery rate was lower in the interventional management. As the 
salvagability and fetal weight were lower, vaginal delivery was preferred in that group. In both the groups, perinatal loss was lower with cesarean delivery. Table 4 shows the maternal outcome in women with preterm severe preeclampsia. Though maternal complications were slightly higher with the expectant management (17\% vs. $11 \%)$, but it was not found to have statistical significance ( $\mathrm{p}$ value 0.815 ). These complications were well managed by multidisciplinary care, indicating institutional supervision of expectant management. The most frequent maternal complication in both the group was abruption, followed by eclampsia in interventional management and HELLP/DIC in expectant management.

Table 5 shows the perinatal outcome in women with preterm severe preeclampsia. The mean prolongation of pregnancy in the expectant management was 7.67 days and it was statistically significant.

Table 3: Mode of delivery in women with preterm severe preeclampsia.

\begin{tabular}{|c|c|c|c|c|}
\hline Mode of delivery & $\begin{array}{l}\text { Interventional management } \\
(\mathrm{n}=100)\end{array}$ & $\begin{array}{l}\text { Perinatal death } \\
(n=63)\end{array}$ & $\begin{array}{l}\text { Expectant management } \\
(\mathrm{n}=100)\end{array}$ & $\begin{array}{l}\text { Perinatal death } \\
(\mathrm{n}=36)\end{array}$ \\
\hline Vaginal delivery & 79 & 51 & 62 & 27 \\
\hline Cesarean delivery & 21 & 12 & 38 & 09 \\
\hline
\end{tabular}

Table 4: Maternal outcome in women with preterm severe preeclampsia.

\begin{tabular}{|lll|}
\hline Maternal complications & Interventional management $(\mathbf{n = 1 0 0})$ & Expectant management $(\mathbf{n}=\mathbf{1 0 0})$ \\
\hline Abruption & 5 & 8 \\
\hline HELLP/DIC & 2 & 3 \\
\hline Eclampsia & 3 & 2 \\
\hline Renal impairment & 0 & 1 \\
\hline Pulmonary edema & 1 & 2 \\
\hline Cerebral edema & 0 & 1 \\
\hline Maternal death & 0 & 0 \\
\hline Total & 11 & 17 \\
\hline
\end{tabular}

Table 5: Perinatal outcome in women with preterm severe preeclampsia.

\begin{tabular}{|llll|}
\hline Perinatal outcome & Interventional management (n=100) & Expectant management (n=100) & 0.0005 \\
\hline Mean latency interval (days) & 2.92 & 7.67 & 0.0005 \\
\hline $\begin{array}{l}\text { Mean gestational age at delivery } \\
\text { (weeks) }\end{array}$ & 30.56 & 31.76 & 0.0005 \\
\hline Mean birth weight (kg) & 1.32 & 1.58 & 0.298 \\
\hline Live birth & 76 & 82 & 0.0005 \\
\hline Still birth & 24 & 18 & 0.0005 \\
\hline Early neonatal death & 39 & 18 & 0.002 \\
\hline Perinatal death & 63 & 36 & 64 \\
\hline Mean neonatal survival rate & 37 & 9.13 & 0.005 \\
\hline Mean hospital stay (days) & 12.57 & & 0 \\
\hline
\end{tabular}

Mean gestational age at delivery and mean birth weight were higher with the expectant management. It was found to have statistical significance. There is no statistically significant difference in live birth and still birth rate between the interventional and expectant management. Early neonatal death, perinatal death and mean hospital stay were lower in the expectant management with statistical significance. Neonatal survival rate was statistically significantly higher with the expectant management. Table 6 shows the latency interval and the perinatal outcome in women with preterm severe preeclampsia. As the latency interval increased the perinatal loss decreased.
Table 6 Latency interval and the perinatal outcome in women with preterm severe preeclampsia.

\begin{tabular}{|llll|}
\hline \multirow{3}{*}{ Management } & $\begin{array}{l}\text { Latency } \\
\text { interval }\end{array}$ & $\begin{array}{l}\text { No. of } \\
\text { patients }\end{array}$ & $\begin{array}{l}\text { Perinatal } \\
\text { death }\end{array}$ \\
\hline \multirow{5}{*}{ Expectant } & 49-72 hours & 53 & 36 \\
& $73-96$ hours & 47 & 27 \\
\hline & $<5$ days & 23 & 16 \\
\cline { 2 - 4 } & 5-8 days & 40 & 13 \\
\cline { 2 - 4 } & $9-12$ days & 29 & 05 \\
\cline { 2 - 4 } & 13-20 days & 06 & 02 \\
\cline { 2 - 4 } & $>20$ days & 02 & - \\
\hline
\end{tabular}




\section{DISCUSSION}

Preterm severe preeclampsia is associated with increased risk of maternal and perinatal morbidity and mortality. Though delivery in women with severe preeclampsia checks the worsening maternal condition, the resultant prematurity is a major risk for neonatal outcome. As controversy exists in the management of preterm severe preeclampsia, analysis of interventional and expectant management is essential.

In interventional management, pregnancy is terminated once the steroid has taken action. Expectant management is terminated only for special maternal and fetal indication. In the current study commonest indication was maternal like imminent eclampsia, uncontrolled blood pressure and abruption. While in the study by Oettle et al and Hall et al fetal distress was the commonest indication for termination of expectant management. ${ }^{3,4}$

The mode of delivery in preterm severe preeclampsia is still debated. Vaginal delivery should be preferred. Cesarean delivery should be reserved for obstetric indication. Fetal compromise may benefit from cesarean delivery. If vaginal delivery is planned and the cervix is unfavorable, cervical ripening should be used to increase the success rate. In present study, the overall vaginal delivery in women with preterm severe preeclampsia was $70.5 \%$, while Oettle et al had reported a higher cesarean delivery $(77.1 \%){ }^{3}$

Interventional management is based on the fact that continuation of pregnancy will increase maternal complications and mortality. Present study and many other studies had not found an increase in maternal complications with expectant management indicating close maternal supervision. ${ }^{5-7}$ Abruption and HELLP were the most frequently reported complications in most studies including present study. ${ }^{3-5,7,8}$ In the present study and in several studies, there was no maternal mortality emphasizing intensive multidisciplinary care in a tertiary care centre. . $^{3-8}$

Expectant management is aimed at prolongation of pregnancy and improving perinatal outcome. In the current study and in few other studies, with expectant management the pregnancy was prolonged by 7 to 14 days. $3,7,8$ This was achieved by appropriate maternal and fetal surveillance. In this study the neonatal survival rate in the expectant management $(64 \%)$ was higher than Interventional management (37\%). Abdel et al and Gracia et al reported a neonatal survival rate of $93 \%$ and $45.5 \%$ respectively ${ }^{7,8}$. Neonatal survival rate depends on the number of days gained and neonatal intensive care facilities. $^{9}$

In this study, perinatal death in the expectant management $(36 \%)$ was lower than interventional management $(63 \%)$. Oettle et al had reported perinatal mortality rate of $44.4 / 1000$ live birth with expectant management, while Gracia et al had found a similar perinatal mortality rate with expectant and interventional management. ${ }^{3,8}$

In the current study, interventional and expectant management had similar maternal outcome in women with preterm severe preeclampsia, but the perinatal outcome is better with expectant management. Obstetric outcome in preterm severe preeclampsia depends on gestational age and the experience of the institution in managing such patients. Randomized controlled trials are needed to confirm or refute these findings and to frame recommendations with concrete evidence. ${ }^{10,11}$

\section{CONCLUSION}

As the risk of maternal and perinatal complications are significantly increased in preterm severe preeclampsia, Expectant management should be done only in well selected patients in a tertiary care centre. Expectant management of preterm severe preeclampsia results in a better obstetric outcome in the form of improved perinatal outcome without prejudicing maternal safety.

\section{Funding: No funding sources}

Conflict of interest: None declared

Ethical approval: The study was approved by the Institutional Ethics Committee

\section{REFERENCES}

1. Briceño Pérez C, Briceño Sanabria L. Evidencebased obstetric conduct. Severe preeclampsia: aggressive or expectant management? Gynecol Obstet Mexico. 2007;75(2):95-103.

2. Sibai BM, Publications Committee, Society for Maternal-Fetal Medicine. Evaluation and management of severe preeclampsia before 34 weeks' gestation. American J Obstet Gynecol. 2011;205(3):191-8.

3. Oettle C, Hall D, Roux A, Grove D. Early onset severe preeclampsia: expectant management at a secondary hospital in close association with a tertiary institution. BJOG. 2005;112(1):84-8.

4. Hall DR, Grove D, Carstens E. Early-preeclampsia: what proportion of women qualify for expectant management and if not, why not? Eur J Obstet Gynecol Reprod Biol 2006;128(12):169-74.

5. Vigil-De Gracia, P., Montufar-Rueda, C., and Ruiz, J. Expectant management of severe preeclampsia and preeclampsia superimposed on chronic hypertension between 24 and 34 weeks' gestation. Eur J Obstet Gynecol Reprod Biol. 2003;107(1):24.

6. Jantasing $\mathrm{S}$, Tanawattanacharoen $\mathrm{S}$ Perinatal outcomes in severe preeclamptic women between 2433(+6) weeks' gestation. J Med Assoc Thai. 2008;91(1):25-30.

7. Abdel-Hady ES, Fawzy M, El-Negeri M, Nezar M, Ragab A, Helal AS. Is expectant management of 
early-onset severe preeclampsia worthwhile in lowresource settings? Arch Gynecol Obstet. 2010; 282(1):23-7.

8. Gracia VP, Tejada RO, Miñaca CAC, Tellez G, Chon VY, Herrarte E, et al. Expectant management of severe preeclampsia remote from term: the MEXPRE Latin study, a randomized, multicenter clinical trial. Am J Obstet Gynecol 2013; 209(5):425.e1-8.

9. Sibai BM. What to expect from expectant management in severe preeclampsia at $<34$ weeks gestation: pregnancy outcomes in developed vs developing countries. Am J Obstet Gynecol. 2013;209(5):400-1.

10. Churchill D, Duley L, Thornton JG, Jones L Interventionist versus expectant care for severe pre- eclampsia between 24- and 34-weeks' gestation. Cochrane Database Syst Rev. 2013 26;(7):CD003106.

11. Magee LA, Yong PJ, Espinosa V, Côté AM, Chen I, von Dadelszen P Expectant management of severe preeclampsia remote from term: a structured systematic review. Hypertens Pregnancy. 2009;28(3):312-47.

Cite this article as: Durairaj A, Management of preterm severe preeclampsia: interventional versus expectant management. Int J Reprod Contracept Obstet Gynecol 2018;7:3931-5. 